ISSN 2236-0859

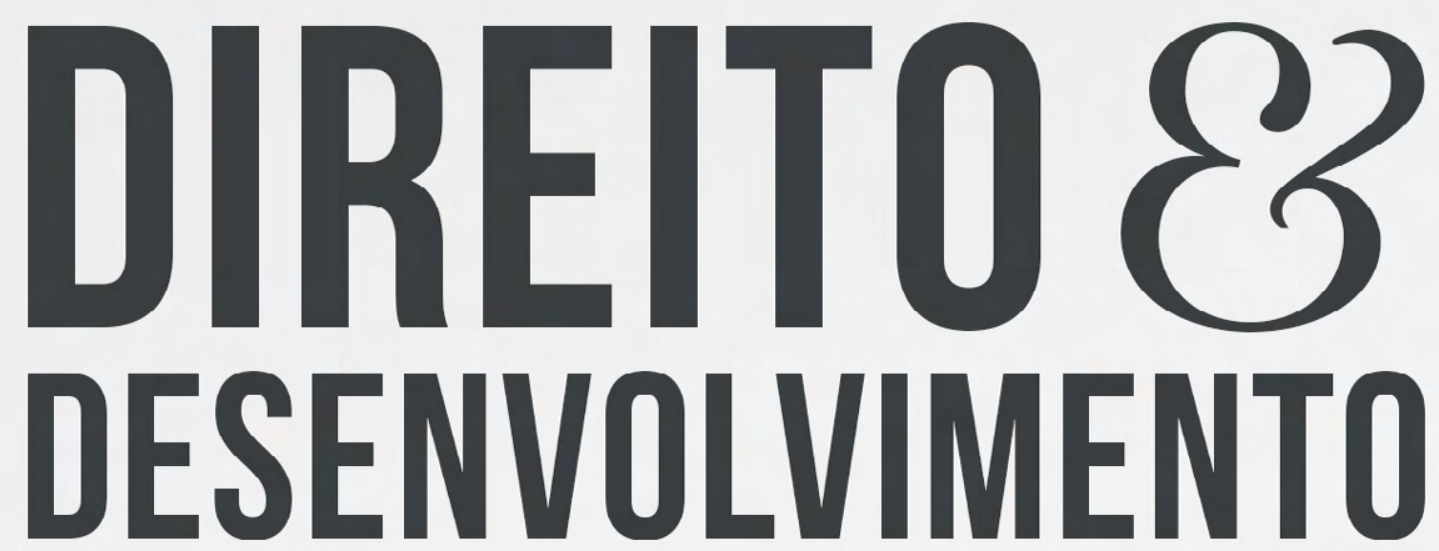

REVISTA DO PROGRAMA DE PÓS-GRADUAÇÃO EM DIREITO MESTRADO EM DIREITO E DESENVOLVIMENTO SUSTENTÁVEL

A EXECUÇ̃̃O NAS AÇ̃ES COLETIVAS: UM DEBATE SOBRE SUA EFETIVIDADE SOB A ÓTICA DO NOVO ORDENAMENTO PROCESSUAL CIVIL

RAFAEL DE OLIVEIRA MONACO

ROGÉRIO BORBA DA SILVA 


\section{A EXECUÇÃO NAS AÇÕES COLETIVAS: UM DEBATE SOBRE SUA EFETIVIDADE SOB A ÓTICA DO NOVO ORDENAMENTO PROCESSUAL CIVIL}

\section{EXECUTION IN COLLECTIVE ACTIONS: A DEBATE ABOUT ITS EFFECTIVENESS FROM THE POINT OF VIEW OF THE NEW CIVIL PROCEDURAL LAW}

Recebido: $10 / 10 / 2018$

Aprovado: 06/11/2018

Rafael de Oliveira Monaco* Rogério Borba da Silva**

RESUMO: O presente artigo tem por objeto tratar da execução de sentença nas ações coletivas a partir das recentes mudanças no ordenamento jurídico processual e como estas repercutiram em um dos momentos processuais menos estudados pelos operadores do direito. Para o alcance do objetivo a pesquisa iniciou pelos aspectos gerais relativos à relevância da execução no cenário atual, no que tange à concretização dos direitos, dentro de um panorama crescente de demandas judiciais. Em seguida tratou-se da classificação da execução e temas específicos como a liquidação da sentença, legitimidade, competência e meios executivos. A pesquisa converge para a demonstração da baixa efetividade das sentenças em ações coletivas o que requer avanços para que a mesma seja percebida pela sociedade e realizada com efetividade pelos operadores do direito.

Palavras-Chave: Ações coletivas. Execução. Efetividade.

ABSTRACT: The purpose of this article is to deal with the execution of a judgment in collective actions based on the recent changes in the legal system of procedure and how these have repercussions in one of the procedural moments less studied by the legal operators. To reach the objective, the research began with the general aspects related to the relevance of the execution in the current scenario, with regard to the realization of rights, within a growing panorama of judicial demands. Next, it dealt with the classification of the execution and specific topics as the liquidation of the sentence, legitimacy, competence and executive means. The research converges to the demonstration of the low effectiveness of the sentences in collective actions which requires advances so that the same is perceived by the society and realized with effectiveness by the operators of the right.

Keyswords: Collective actions. Verdict. Execution. Effectiveness.

\section{INTRODUÇÃO}

É conhecida a máxima de Chiovenda (1969, p. 46) pela qual, na "medida do que for praticamente possível o processo deve propiciar a quem tem um direito tudo aquilo que ele

\footnotetext{
* Juiz de Direito do Tribunal de Justiça do Estado do Rio de Janeiro. Possui graduação pela Universidade Cândido Mendes (2001). E-mail: rafaelomonaco@gmail.com

** Doutor em Sociologia pela Universidade Candido Mendes (2017). Atualmente é professor de Direito do Instituto Brasileiro de Mercado de Capitais, da Universidade Estácio de Sá e do Centro Universitário Carioca. E-mail: rogerioborba@gmail.com
} 
enha um direito de obter". Em outras palavras, processo sem resultados é instrumento sem função.

Nesse sentido, o exercício da jurisdição deixou ser encarado sob uma ótica romântica ${ }^{2}$ ou bucólica. O jurisdicionado não quer uma sentença poética, uma obra doutrinária meramente declamatória de direitos. Ele anseia pelo bem da vida pretendido, ou seja, a satisfação de seu direito, em tempo célere e razoável. Com efeito, a jurisdição se tornou uma unidade de produção, diante da avassaladora quantidade de feitos em curso no país, a desafiar constantemente os operadores do direito nessa tarefa hercúlea de prestação jurisdicional. Os números não mentem ${ }^{3}$. Basta constatar a existência de cerca de 80 milhões de processos em andamento no país, a caracterizar um demandismo desenfreado ${ }^{4}$. A questão, portanto, não é mais de "Acesso à Justiça", mas de saída dela, sob pena de colapso ${ }^{6}$ do próprio sistema.

Particularmente, a execução, em sentido amplo, contribui para esse panorama caótico. Pode se dizer que a efetivação dos julgados e dos títulos executivos extrajudiciais constitui o gargalo do sistema7 ${ }^{7}$. Isto porque representa o maior acervo, em taxa de congestionamento processual, chegando, no Rio de Janeiro (TJRJ EM NÚMEROS, 2018), a corresponder a 94,13\%, nos processos em $1^{\circ}$ grau de jurisdição e 55,22\%, em relação aos Juizados Especiais, constituindo uma das Metas Nacionais ${ }^{8}$ e permanente do CNJ para o aperfeiçoamento dos Sistema da Justiça.

Aliás, se atualmente o processo de execução é visto com "bons olhos”, nem sempre assim o foi na história do processo civil. Por retratar uma atividade prática, material, sancionatória e satisfativa, sem cunho, exclusivamente, cognitivo, a execução sempre foi considerada o "patinho feio" ou o "primo pobre" do processo civil. Sofria, assim, de um preconceito científico, como se fosse uma ciência de menor importância, subalterna, tanto que apelidado como a "Cinderela9" do processo. Essa visão, contudo, ficou no passado. Se o século XX foi marcado

2 É importante a advertência do professor Dierle Nunes (2013, p. 33-34): “O estudo da Ciência Processual há muito deixou de se limitar a uma discussão tão somente teórica, na qual se buscavam delimitar os institutos processuais e as teorias que tratavam de sua trilogia estrutural (processo, jurisdição e ação). Do mesmo modo, não se pode também analisá-la somente em perspectiva técnica instrumental, nos moldes tradicionais, em que o processo serviria à aplicação do Direito material, buscando uma utópica paz social. Essas perspectivas, apesar de sua importância em seu tempo, cedem espaço para uma análise da ciência processual que busca uma efetividade normativa (Rechtsschutzeffektivität), ou seja, uma aplicação dos institutos processuais de acordo com os princípios e regras constitucionais, de modo a ofertar, concomitantemente, legitimidade e eficiência na aplicação do direito".

3 Durante o ano de 2016, ingressaram 29,4 milhões de processos e foram baixados 29,4 milhões. Mesmo tendo baixado praticamente o mesmo quantitativo ingressado, com Índice de Atendimento a Demanda na ordem de 100,3\%, o estoque de processos cresceu em 2,7 milhões, ou seja, em 3,6\%, e chegou ao final do ano de 2016 com 79,7 milhões de processos em tramitação aguardando alguma solução definitiva. CNJ. Justiça em números 2017, p. 67.

4 Para se ter uma ideia, os Juizados Especiais Cíveis do Estado do Rio de Janeiro receberam, somente em maio de 2018, mais 28,6 mil ações contra empresas, o que representa um aumento de quase $10 \%$ em relação a abril, quando foram distribuídos 26.130 processos. 5 “Cobrado por sua ineficiência, o juiz brasileiro está se transformando no juiz-Bartleby, o juiz que 'prefere não pensar", optando pela replicação, pela automatização, pela decisão-cópia e pela jurisprudência defensiva. Afogado em quase 100 milhões de processos, a produção em série parece ser a única resposta possível, ao passo que estatísticas dos serviços médicos dos Tribunais revelam um aumento preocupante do número de magistrados adoecidos pelo stresse. Os órgãos responsáveis pelo governo do Poder Judiciário têm mais do que simplesmente incentivado, tem exigido dos juízes esse comportamento replicante, quantitativo, que acaba por reduzir a sentença a um produto serial e os direitos a mercadoria. Transita-se na pura indistinção entre cidadania e mercado. Caminhamos para a pura catatonia judiciária, para o imobilismo processual imposto pelo titânico volume de ações judiciais, sem precedentes no mundo, pelo bacharelismo gongórico, pela teorética abstrata e pelo gerencialismo modernoso. No Brasil, a questão não é mais de "acesso" ao judiciário, senão de "saída" desse labirinto forense (RESENDE JÚNIOR, 2014).

6 "Analisando o Poder Judiciário como um todo, tais diferenças significam que, mesmo que o Poder Judiciário fosse paralisado sem o ingresso de novas demandas e mantida a produtividade dos magistrados e dos servidores, seriam necessários aproximadamente 2 anos e 8 meses de trabalho para zerar o estoque". CNJ. Justiça em números 2017, p. 67.

7 A cada ano, a publicação do Relatório Justiça em Números destaca o impacto negativo gerado pela fase de execução nos dados de litigiosidade do Poder Judiciário brasileiro, que acumula alto volume processual e alta taxa de congestionamento. Esse volume dificulta a efetivação da tutela jurisdicional. Para ilustrar, o Poder Judiciário contava com um acervo de 8o milhões de processos pendentes de baixa no final do ano de 2016, sendo que mais da metade desses processos (51,1\%) se referia à fase de execução. CNJ. Justiça em números 2017, p. 109.

8 META 5 - Impulsionar processos à execução (Justiça Estadual, Justiça Federal e Justiça do Trabalho). Na Justiça Estadual: estabelecer política de desjudicialização e de enfrentamento do estoque de processos de execução fiscal, até 31/12/2017. Na Justiça Federal: baixar quantidade maior de processos de execução não fiscal do que o total de casos novos de execução não fiscal no ano corrente. Na Justiça do Trabalho: baixar 90\% do total de casos novos de execução do ano corrente, com redução proporcional, em cada tribunal, à redução do número de juízes e de servidores cujos cargos não foram repostos (ENCONTRO NACIONAL DO PODER JUDICIÂRIO, 2016, p. 2). 9 "É do passado o vício metodológico consistente em tratar os temas do processo civil e encará-los pelo prisma exclusivo do processo de conhecimento, negligenciando sua projeção à execução e tratando os fenômenos inerentes a esta como se fizessem parte de outro 
pelo reconhecimento do processo de cognição, em seu movimento de autoafirmação como ciência autônoma, galgadas as fases do imanentismo ao instrumentalismo, o século XXI é a era da Execução.

O artigo se insere no ramo das Ciências Jurídicas e Sociais, nas áreas do Direito Processual Civil, sendo analisada em uma perspectiva histórica e ontológica.Apresentase, então, o seguinte questionamento: a Execução é devidamente conduzida nos processos coletivos? A hipótese trabalhada reconhece a limitação na sua aplicação, devendo receber um olhar mais atento. Objetiva-se, com isso, avaliar a necessidade de aprofundamento no estudo da execução nos processos coletivos. A metodologia adotada foi a bibliográfica e documental. A relevância acadêmica da pesquisa se demonstra no sentido de contribuir para o reconhecimento e consolidação da execução nos processos coletivos.

O Estado teve o seu perfil alterado. A sociedade evoluiu, novos direitos foram reconhecidos e modificou-se às expectativas em relação à Justiça. Assim, é preciso mais do que nunca, em nome da credibilidade de sua imagem, que se tornem concretos os comandos jurisdicionais.

Logo, o processo civil, nos dias atuais, é muito mais Execução do que declaração. A exigência de proteção dos direitos reclama uma resposta concreta e não meramente declaratória. Tomou-se consciência da real significância da execução e da sua superlativa importância ${ }^{10}$ para a manutenção do sistema, notadamente, em uma sociedade de produção de massas, lesão de massas e demandas em massas.

\section{AS AÇÕES COLETIVAS}

Como ensina Marinoni, Arenhart e Mitidiero (2017, p. 473), a respeito da filosofia das ações coletivas, "a sociedade moderna caracteriza-se por uma profunda alteração no quadro dos direitos e na sua forma de atuação".

De fato, a tutela dos direitos difusos, coletivos e individuais homogêneos ${ }^{11}$, amparadas sob o domínio das chamadas "ondas renovatórias", preconizadas por Mauro Cappelletti e Bryan Garth (1998), constituiu uma verdadeira revolução na sistemática processual brasileira, uma vez que o modelo processual, de perfil individual, marcado por uma ótica patrimonial e ressarcitória, inerentes às antigas codificações, não atendia mais aos reclames da coletividade.

Havia, portanto, a necessidade de reformulação dos esquemas processuais tradicionais para atender, adequadamente, as pretensões da sociedade contemporânea. É nesse contexto que surge a figura do "processo coletivo", influenciada pelas class action norte-americanas, buscando, através de uma tutela jurídica diferenciada ${ }^{12}$, o atendimento a direitos de toda

universo de menor dignidade científica (a execução seria um verdadeira Cinderela da ciência processual). Tratavam-na de modo empírico e, no máximo, ofereciam-lhe em empréstimo certos conceitos vindos do processo de conhecimento. As peculiaridades dos institutos inerentes à execução forçada não são dotadas de tanta magnitude, que pudessem dar-lhes vida própria e subtraí-los à teoria geral, mas também não são tão colaterais ou circunstanciais, a ponto de serem renegadas a um plano de menor dignidade no sistema" (DINAMARCO, 2009, p. 32-33).

10 Dessas três funções [conhecimento, execução e cautelar], conforme se dessume de seus conceitos, a mais relevante é a execução. Com efeito, assume escassa relevância, na sociedade de massas, onde há uma generalizada aspiração à efetividade do direito, a simples outorga de certeza à parte, a solene declaração de que ostenta direito, objetivo precípuo da função de conhecimento. Tampouco bastará assegurar tal direito, finalidade básica e função cautelar. O que importa, na realidade, é efetivar o direito, concreta e plenamente, alcançando o bem da vida ao seu titular, sem maiores demoras e despesas. E este constitui o escopo da execução (ASSIS, 1996, p. 46-52).

11 Ver art. 81 da lei 8078/90.

12 "O tema das tutelas diferenciadas ou das "tutelas jurisdicionais diferenciadas", passou a ser objeto do debate da ciência processual a partir do trabalho de Proto Pisani publicado em1973, partindo-se, como pressuposto óbvio, da necessidade de diversidade de técnicas processuais para as diversas hipóteses de direito material a ser aplicado e analisando que a questão somente poderia ser devidamente colocada em discussão a partir daquele momento histórico em face da viabilidade de pensar uma quebra do modelo neutro e único de processos ordinários de cognição plena, presumidamente predispostos a permitir o julgamento de qualquer caso. Os modelos processuais diferenciados seriam delineados com a intenção de garantir as mais idôneas formas de tutela para as várias categorias de 
a coletividade (difusos), de uma classe de pessoas ligadas por uma relação jurídica de base (coletivos) ou mesmo de um grupo unido por uma situação de fato (individuais homogêneos), mas com um viés não exclusivamente patrimonial (no money judgments), de caráter preventivo e cujo resultado alcançasse uma execução específica não redundado em meras perdas e danos.

Dados do $\mathrm{CNJ}^{13}$ demonstram que, em 2014, foram ajuizadas 34.587 ações civis públicas. Já em 2015, houve um aumento na ordem de $47 \%$, sendo distribuídas 50.858. O último resultado apontado demonstrou que, em 2016, houve uma leve queda do percentual alcançando-se o total de 48.118 demandas de tal natureza.

Isso comprova a alta relevância das ações coletivas, no cenário nacional, que ainda soa como um tabu para muitos intérpretes. Em verdade, ainda se encara o processo coletivo como um instituto místico ou esotérico, uma ciência para poucos iniciados, não se podendo valer da compreensão dos institutos tradicionais de litigiosidade individual para a leitura do novel instrumento, comprometo-lhe o potencial ${ }^{14}$.

Plasmado neste novo ideário é que surgiu, a par da lei 7.347/85 (Ação Civil Pública LACP), outros diplomas legais, a exemplo da lei 4.717/65 (Ação Popular), lei 8.o78/9o (Código de Defesa do Consumidor - CDC), lei 8.o69/9o (Estatuto de criança e Adolescente - ECA), lei 10.741/o3 (Estatuto do Idoso), lei 12.016/o9 (Mandado de Segurança), lei 7.913/89 (Proteção aos investidores no mercado mobiliário ), lei 12.529/11 (proteção e defesa da concorrência) entres outros, naquilo que restou denominado de microssistema de tutela coletiva (DIDIER JUNIOR; ZANETI JUNIOR, 2009; DONIZETTI; CERQUEIRA, 2010), dado que ainda não contamos com uma codificação una que albergue todas as questões envolvidas.

No que tange à Execução, a lei 7.347/85, não obstante os avanços normativos, refletindo uma postura legislativa e doutrinária vigente à época, a respeito da diminuta importância da matéria, apenas dedicou três disposições legais, especificamente, os artigos $11^{15}, 13^{16}$ e $15^{17}$, deixando uma grande lacuna colmatada pelas regras extravagantes, de aplicação subsidiária, até o $\mathrm{CPC} / 73$.

Pois bem, admitida, portanto, uma tutela coletiva afigura-se correta a expressão "execução coletiva"? Na doutrina ${ }^{18}$, há quem entenda que a terminologia é incorreta, a fim de que não seja confundida com o sistema de insolvência mercantil. No entanto, tendo em vista que modernamente a falência é vista como um processo de execução concursal, havendo uma variedade de credores dispostos consoante uma ordem de preferência legal (art. 83 da

situações jurídicas merecedoras de tutela jurisdicional" (NUNES, 2013, p. 443).

13 Poder Judiciário. Justiça em números digital, demandas por classe e assunto, ano 2014, ano 2015, ano 2016. Classe - casos novos, pesquisar: "AçãoCivil Pública”. Disponívelem<https://paineis.cnj.jus.br/QvAJAXZfc/opendoc.htm?document=qvw_1\%2FPainelCNJ. qvw\&host=QVS\%4oneodimioo3\&anonymous=true\&sheet=shResumoDespFT>. Acesso em 15 jul. 2018.

14 É proveitosa, mais uma vez, a lição de Marinoni, Arenhart e Mitidiero (2017, p. 474): "É preciso, pois, para bem operar com as ações coletivas, despir-se de velhos preconceitos (ou pré-conceitos), evitando recorrer a raciocínios aplicáveis apenas à "tutela individual”, para solucionar questões atinentes à "tutela coletiva”, que não é, e nem pode ser pensada, sob a perspectiva da teoria geral da ação individual. Os institutos que presidem essa ação (ao menos em sua grande maioria) são incompatíveis e inaplicáveis à tutela coletiva, simplesmente por que foram concebidos para operar em outro ambiente. Em que pese o fato de o direito nacional estar munido de suficientes instrumentos para a tutela das novas situações de direito substancial, o despreparo para o trato com esses novos e poderosos mecanismos vem, nitidamente, minando o sistema e transformando-o em um ente teratológico que flutua no limbo".

15 Art. 11. "Na ação que tenha por objeto o cumprimento de obrigação de fazer ou não fazer, o juiz determinará o cumprimento da prestação da atividade devida ou a cessação da atividade nociva, sob pena de execução específica, ou de cominação de multa diária, se esta for suficiente ou compatível, independentemente de requerimento do autor".

16 Art. 13. "Havendo condenação em dinheiro, a indenização pelo dano causado reverterá a um fundo gerido por um Conselho Federal ou por Conselhos Estaduais de que participarão necessariamente o Ministério Público e representantes da comunidade, sendo seus recursos destinados à reconstituição dos bens lesados".

17 Art. 15. "Decorridos sessenta dias do trânsito em julgado da sentença condenatória, sem que a associação autora lhe promova a execução, deverá fazê-lo o Ministério Público, facultada igual iniciativa aos demais legitimados”.

18 Por todos, Wilges Bruscato (2009, p. 3) no seguinte sentido: "entendemos que esta não seria a melhor denominação a ser adotada, visto que execução coletiva denota concurso, tal como na falência ou na insolvência civil (...) Para o tipo de execução de ação da qual trataremos neste trabalho, entendemos que as expressões tutela executiva da ação coletiva ou execução de tutela coletiva são mais precisas. Com as reformas introduzidas recentemente no CPC, também é possível a referência ao cumprimento de tutela coletiva”. 
lei 11.101/05), inexiste impeditivo normativo ou semântico que impeça o uso da já consagrada denominação para os casos de demandas de tal natureza.

\section{CLASSIFICAÇÃO DA EXECUÇÃO COLETIVA}

À exemplo da execução tradicional, a execução coletiva também se submete à classificação. Existem diversos critérios pelos quais a execução pode ser classificada. Nem sempre a doutrina as reúne de maneira uniforme. Para fins didáticos, contudo, pode-se compreender e sistematizar o estudo da atividade executiva, tendo por conta a origem do título; à natureza do direito; à espécie da obrigação e à estabilidade do título.

A primeira classificação diz respeito a origem título executivo. Tendo em vista que a existência de título executivo é fundamental ao processo de execução, como pressuposto formal, na dicção do art. $783^{19}$ do $\mathrm{CPC} / 2015$, este pode derivar de um reconhecimento judicial ou mesmo de uma atribuição legal. Decorrem daí que os títulos executivos podem ser judicias (art. 515 do CPC/15) ou extrajudiciais (art. 784 do CPC/2015).

O exemplo mais notório deste último título, para fins coletivos, reside no chamado "termo de ajustamento de conduta", na forma do art. $5^{\circ}$, $§ 6^{\circ}$ da lei $7 \cdot 347 / 85^{20}$. Outro interessante exemplo são as decisões do CADE (Conselho Administrativo de Defesa Econômica) que gozam de eficácia processual abstrata, a teor do art. 93 da lei 12.529/1121.

Quanto à natureza do direito, na dicção do art. 81, parágrafo único da lei 8078/90, estes podem ser difusos, coletivos e individuais homogêneos. A distinção é de imperiosa importância, diante das diferenças no tocante à legitimidade, competência, prazo e meios de execução (GRINOVER, 1999).

Ademais, é neste contexto que se dualiza o tratamento normativo a ser dado à execução coletiva. O motivo é simples. Somente haverá execução coletiva propriamente dita nos casos de direitos/interesses difusos e coletivos, uma vez que a transindividualidade se mantém inalterada do início ao fim do processo.

Todavia, nos casos de direitos individuais homogêneos, apenas a fase cognitiva possui o perfil coletivo, ou seja, tais direitos, são tratados pela lei ${ }^{22}$ como "acidentalmente homogêneos" com o escopo de facilitar a tutela jurisdicional. Após a resolução do mérito, por meio do julgamento da demanda, retornam à sua condição individual voltando a se apresentar como heterogêneos, dando origem a uma multiplicidade de execuções individuais.

Prova disto é o art. 95 do CDC ao anunciar que a condenação será genérica fixando a responsabilidade do réu pelos danos causados, devendo a vítima ou seus sucessores promoverem a respectiva liquidação prévia à execução do julgado.

Em resumo, em sede de tutela coletiva poderão coexistir a execução coletiva propriamente dita e a execução individual, nos termos em que se verá no presente estudo.

Em relação à espécie da obrigação, aqui inexiste diferença em relação à execução tradicional. Utiliza-se o critério haurido do direito material, de maneira que a lei processual guarde regras apropriadas para a realização concreta da obrigação estampada no título. Isto é, à natureza do direito corresponde o tipo ou modalidade de tutela jurisdicional. Logo, se

19 Art. 783. "A execução para cobrança de crédito fundar-se-á sempre em título de obrigação certa, líquida e exigível”. 20 "Os órgãos públicos legitimados poderão tomar dos interessados compromisso de ajustamento de sua conduta às exigências legais, mediante cominações, que terá eficácia de título executivo extrajudicial”.

21 Art. 93. "A decisão do Plenário do Tribunal, cominando multa ou impondo obrigação de fazer ou não fazer, constitui título executivo extrajudicial".

22 Art. 91 do CDC. "Os legitimados de que trata o art. 82 poderão propor, em nome próprio e no interesse das vítimas ou seus sucessores, ação civil coletiva de responsabilidade pelos danos individualmente sofridos, de acordo com o disposto nos artigos seguintes". 
mostram cabíveis, na execução coletiva, as pretensões relativas às obrigações de dar, fazer/não fazer e pagar quantia certa.

No que tange à estabilidade do título, a execução coletiva também poderá ser definitiva ou provisória, sendo esta última nos moldes preconizados do art. 520/522 do CPC/2015. A regra tem a sua razão de ser. É que se tratando, a execução, da realização de atos materiais satisfativos em que existe agressão patrimonial à esfera jurídica alheia, é preciso que haja um mínimo de cautela e de segurança jurídica, quando o título judicial não esteja revestido de trânsito em julgado.

Isto é, o título enquanto não isento de dúvidas, posto que submetido a recurso, exige a lei que a execução se faça sob determinadas condições. É a aplicação do princípio da responsabilidade do exequente (art. 520 do $\mathrm{CPC} / 2015$ ) a exigir, em caso de execução injusta, a reparação dos danos causados ao executado, com a restituição do estado anterior, bem como a exigência de caução para o levantamento de depósitos ou atos que importem em alienação de domínio.

No entanto, em sede de execução coletiva esta regra deve ser abrandada para dispensar a exigência de caução para os entes públicos legitimados à execução dos direitos difusos, frente a uma interpretação que amplie a potencialidade de eficácia do tipo de tutela levada e efeito.

A regra do CPC, disposta para as lides individuais, não deve constituir fator de restrição para as lides coletivas, sob pena de subversão ao sistema de efetividade da execução coletiva caindo no erro de aplicação dos instrumentos com os olhos voltados apenas para o CPC, em franca interpretação míope dos institutos ${ }^{23}$. A jurisprudência caminha nesta direção ${ }^{24}$.

\section{A LIQUIDAÇÃO DE SENTENÇA}

Embora seja natural que uma obrigação reconhecida em sentença ostente todos os atributos aptos a deflagrar a via executiva, assim nem sempre procede. Existem situações em que o próprio Código de Processo Civil permite a prolação de uma sentença incompleta, ou seja, um título que não permita de plano o manejo da execução ${ }^{25}$. São os casos de pedidos genéricos, a teor do art. 324, parágrafo único do CPC/2015.

Nestas situações, depois do ato de reconhecimento do direito, a obrigação passa por uma etapa de acertamento, um filtro processual que lhe permita individualizar, em completo, todos os atributos objetivos e subjetivos para o aparelhamento executivo. Logo se vê que a liquidação não é propriamente da sentença, mas da obrigação que lhe dá suporte ${ }^{26}$.

A liquidação, portando, constitui uma atividade judicial integrativa, de natureza cognitiva, com vistas a complementar a norma jurídica individualizada no título executivo. 23 No sentido do texto, Ricardo de Barros Leonel (2013, p. 411-421) expõe: "Exigir-se caução para os atos de execução provisória coletiva, considerando as características dos entes legitimados, é contrariar os princípios da efetividade, instrumentalidade e inafastabilidade da jurisdição, impedindo que a tutela assegure a quem tenha um direito exatamente aquilo que deve receber, de modo similar à tentativa de impedimento de acesso à justiça vertente dos atos normativos que vedam à concessão de liminares contra o poder público.

24 TJSP - Agravo de Instrumento. Ação Civil Pública em fase de execução provisória de sentença. Decisão que deferiu a realização de leilão de veículo de propriedade da executada, independentemente de caução. Viabilidade do cumprimento provisório da sentença (art. 520 do CPC), dispensada a prestação de caução por parte do Ministério Público. Presunção de idoneidade financeira do Poder Público que afasta risco de dano ao executado, em razão da solvência garantida. Precedentes do STJ e desta Corte. Recurso improvido, mantida e ratificada a decisão que indeferiu o efeito suspensivo (AI. 2200o99-59.2017.8.26.oooo; Relator (a): Aroldo Viotti; Órgão Julgador: 11 ${ }^{\mathrm{a}}$ Câmara de Direito Público; Data do Julgamento: 09/02/2018; Data de Registro: 09/02/2018).

25 “Tem sabor de obviedade, mas não custa dizer que não seria possível realizar no plano prático, nem provisória, nem definitivamente, uma norma jurídica ainda incompleta ou quase completa. A falta de alguns elementos do direito exequendo impede a realização da atuação executiva" (ABELHA, 2017, p. 435).

26 Esclarece Rodrigo Mazzei e Tiago Figueiredo Gonçalves (2014, p. 2) que: "A decisão que certifica a obrigação indeterminada não é objeto de liquidação, mas possibilita a abertura da via na qual a atividade de liquidação vai ser realizada. Quando, então, o Código alude à "liquidação de sentença", faz uso da figura de linguagem denominada de hipálage, que consiste em "figura de retórica pela qual se atribui a uma ou mais palavras de uma frase o que logicamente pertence a outra ou a outras da mesma frase”. 
Forma-se, então, um título complexo, oriundo da sentença judicial reconhecedora do direito acrescido da decisão liquidanda, que abrirá as portas da execução forçada.

Em que pese à ausência de regras sobre a liquidação de sentença, no âmbito na LACP, ao tema deve ser aplicado a previsão contida no $C D C$ e, residualmente, no próprio $C P C$, mantidas as particularidades inerentes ao processo coletivo.

Pois bem, com a reforma processual, a liquidação, não obstante o seu caráter acionário ${ }^{27}$, perdeu a autonomia para se traduzir em uma mera etapa processual - fase incidental - em homenagem ao sincretismo processual. Vale dizer, conhecimento, liquidação e execução se desenvolvem na mesma relação processual, sem solução de continuidade.

No entanto, muito embora o sistema tenha adotado a figura do processo multifases, nem sempre isso acontece. A regra do art. 515, §1으 do CPC/2015 excepciona tal situação, nos casos de sentença penal condenatória, sentença arbitral, sentença estrangeira homologada pelo Superior Tribunal de Justiça (STJ) e decisão interlocutória estrangeira após a concessão de exequatur à carta rogatória pelo STJ. Em tais casos, inexiste um módulo processual anterior em que se possa promover a liquidação como um apêndice. Será preciso, pois, um processo autônomo.

Essa distinção também é aplicável na seara do processo coletivo para a execução de direitos individuais homogêneo ${ }^{28}$, em autêntica exceção heterotópica. Aqui não se trata de mera fase liquidanda. Amplia-se o objeto de liquidação para a definição não só do valor devido (quantum debeatur), mas, principalmente, para a demonstração do dano, da prova do nexo causal e da pertinência subjetiva do credor (cui debeatur). Fala-se, então, em falsa liquidação ou liquidação imprópria, dada a grande extensão de temas a serem identificados ${ }^{29}$. O que se tem, portanto, não é propriamente uma fase de individualização da obrigação, mas uma demanda autônoma de perfil cognitivo ${ }^{30}$, cujo resultado pode ser zero ${ }^{31}$, bastando que o interessado não consiga demonstrar os fatos constitutivos de seu direito.

Por fim, dispõe o art. 1015, parágrafo único do $\mathrm{CPC}^{32}$ que será cabível o recurso de Agravo de Instrumento contra as decisões proferidas na fase de liquidação. Ora, como se trata de mera extensão do módulo processual de conhecimento, cujo mérito já foi resolvido na sentença, não desafiaria a apelação. Essa a lógica do sistema já vigente ao tempo do art. $475-\mathrm{H}$ do $\mathrm{CPC} / 73$, com a redação dada pela lei 11.232/2005, não de podendo falar em fungibilidade $33 / 34$, ainda que certa doutrina se mostre refratária a ela (ASSIS, 2009, p. 129).

27 "O legislador do CPC/2015 optou por utilizar a expressão "fase de liquidação" (v. p. ex., art. 1015, parágrafo único). Mas a liquidação não é mero incidente processual, integrante da ação de conhecimento ou da ação de execução, e, sim, verdadeira ação, de que a parte lança mão quando já proferida a sentença condenatória (WAMBIER, 2018, p. 127).

28 Conforme explica Vicente de Paula Ataíde Junior (2007, p. 281), "além dessas quatros hipóteses - sentença penal, sentença arbitral, sentença estrangeira e sentença que condene a Fazenda Pública a pagar dinheiro - existe também uma quinta, de processo autônomo de execução, agora fora das previsões do Código de Processo Civil: a execução individual de sentença coletiva.

29 Todavia, há casos em que, sob o nome de "liquidação", faz-se mais do que apurar o quantum debeatur. Procede-se à própria identificação da existência de danos, e até mesmo, do nexo de causalidade entre a conduta ilícita do (hipoteticamente) "condenado" e o dano averiguado. (...) Pode-se falar, em tais casos, em um procedimento de "falsa liquidação" (WAMBIER, 2018, p. 136).

30 Pense-se, por exemplo, no famoso caso do laboratório médico que fraudou os componentes de um anticoncepcional, tornando-o ineficaz, o que ensejou a gravidez de diversas usuárias. Condenada a empresa, em sede de Ação Civil Pública, a indenizar os danos causados as consumidoras, estas terão que demonstrar que engravidaram (dano) com o uso do contraceptivo (nexo causal), além dos demais gastos inerentes ao estado gravídico. Vê-se, pois, que a questão transborda os limites de uma simples liquidação incidental. 31STJ - Processual Civil (...). "Liquidação zero". Título executivo que encarta crédito inexistente. Obrigação inexigível. 1. A liquidação de sentença pode ensejar a denominada "liquidação zero" quando não há o que pagar a título de quantum debeatur" em decisão de eficácia puramente normativa. (...) (REsp 802.011/DF, Rel. Ministro Luiz Fux, primeira turma, julgado em 09/12/2008, DJe 19/02/2009).

32 Também caberá agravo de instrumento contra decisões interlocutórias proferidas na fase de liquidação de sentença ou de cumprimento de sentença, no processo de execução e no processo de inventário.

33 STJ - Recurso Especial - Processual Civil - Decisão que homologa pedido de liquidação de sentença proferida em ação civil pública - recurso cabível - agravo de instrumento - (...) (REsp 1118249/ES, Rel. Ministra ELIANA CALMON, SEGUNDA TURMA, julgado em 27/10/2009, DJ 25/11/2009).

34 TJRJ - Apelação Cível. Decisão que encerra a liquidação de sentença. Interposição de recurso de apelação. Via recursal eleita inadequada. Inteligência do parágrafo único, do artigo 1.015, do CPC/2015. Decisão interlocutória que deveria ter sido atacada por agravo de instrumento. Recurso não conhecido. oo93738-98.2004.8.19.0oo1 - Apelação - Des (a). José Roberto Portugal Compasso - 


\section{LEGITIMIDADE}

Dado que a execução poderá ser coletiva ou individual, a questão concernente à legitimidade também oferece algumas considerações. Para a pertinência subjetiva na lide, não se pode perder de vista que, como regra geral, é o titular da relação jurídica material que deve estar em juízo para a defesa de seu direito (legitimidade ordinária), não sendo facultado a terceiros, salvo autorização legal ${ }^{35}$, agir em nome próprio na defesa de um direito alheio, na qualidade de substituo processual (legitimidade extraordinária).

Em se tratando de execução de direitos difusos, em virtude da indivisibilidade e indeterminação do sujeito titular, em nome da denominada representação adequada, poderão promover o cumprimento da sentença os legitimados previstos no art. $5^{\circ} \mathrm{c} / \mathrm{c}$ o art. 13 da LACP, cujo montante será revertido em favor de um fundo (fluid recorevy) destinado à restauração dos bens jurídicos violados. Haverá aqui uma legitimidade extraordinária concorrente e disjuntiva ${ }^{36}$.

Nesta última hipótese, contudo, durante o decurso do prazo de 6o dias, após o trânsito em julgado, terá o autor da demanda coletiva, uma legitimidade exclusiva para a execução, sob pena de haver uma indevida disputa entre os legitimados para assumir a figura como exequente, o que ensejaria um tumulto processual, a todo desnecessário neste campo (MARINONI; ARENHART; MITIDIERO, 2017, p. 497) ${ }^{37}$.

Ao contrário da sistemática legal do $\mathrm{CPC} / 2015$, a consagrar um princípio de disponibilidade da execução, a teor do art. $775^{38}$, em razão da presença de interesses patrimoniais disponíveis, no caso de execução coletiva vige o princípio da obrigatoriedade da execução, tanto assim, que, em caso de inércia dos demais legitimados deverá o Ministério Público assumir a frente processual.

Entretanto, para além da execução coletiva pelos legitimados do art. $5^{\circ}$ da LACP, prevê o CDC, no art. 103, $3^{\circ}$ 39, que as vítimas ou seus sucessores, se valendo do título executivo obtido na ação civil pública, possam buscar a respectiva indenização. Isto é, traslada-se o título obtido em ação coletiva em favor de uma execução individual. É a denominada execução in utilibus derivado da coisa julgada secundum eventum litis ${ }^{40}$.

Quer isso demonstrar que, em razão da condenação por um dano ambiental, promovida pelo Ministério Público, em Ação Civil Pública, poderá o lesado particular, em caso de procedência do pedido, se valer deste título executivo, embora não tenha participado da relação processual, para assim promover a "liquidação da sentença" com a posterior execução em seu favor.

\footnotetext{
Julgamento: 17/05/2017 - nona câmara cível.

35 Art. 18 CPC/15. "Ninguém poderá pleitear direito alheio em nome próprio, salvo quando autorizado pelo ordenamento jurídico". 36 Art. 15. "Decorridos sessenta dias do trânsito em julgado da sentença condenatória, sem que a associação autora lhe promova a execução, deverá fazê-lo o Ministério Público, facultada igual iniciativa aos demais legitimados".

37 Em argumento contrário, Elpídio Donizete e Marcelo Malheiros Cerqueira (2010, p. 384), para quem o dispositivo legal [art.15 da LACP] "não implica vedação a que um dos legitimados à defesa dos direitos coletivos em juízo que não atuou na fase de conhecimento promova o cumprimento da sentença coletiva antes do transcurso do prazo de 6o (sessenta) dias. Afinal, se a legitimação extraordinária para as demandas é disjuntiva para assegurar o amplo acesso à justiça das coletividades, não se afigura lógico manter a independência da atuação dos substitutos processuais apenas na fase de conhecimento do processo coletivo. O prazo fixado no art. 15 da LACP, portanto, tem o objetivo de servir de parâmetro apenas à atuação obrigatória do Ministério Público, em caso de omissão dos demais legitimados".

38 Art. 775. "O exequente tem o direito de desistir de toda a execução ou de apenas alguma medida executiva".

39 Art. 103. $\$ 3^{\circ}$ do CDC. "Os efeitos da coisa julgada de que cuida o art. 16, combinado com o art. 13 da Lei $n^{\circ} 7.347$, de 24 de julho de 1985, não prejudicarão as ações de indenização por danos pessoalmente sofridos, propostas individualmente ou na forma prevista neste código, mas, se procedente o pedido, beneficiarão as vítimas e seus sucessores, que poderão proceder à liquidação e à execução, nos termos dos arts. 96 a $99 "$

40 Como ensina Ada Pellegrini Grinover et al (1999, p. 826) "o §3ํㅡㄹ do art. 103 inova profundamente com relação aos princípios processuais sobrea coisa julgada: inspirado no princípio da economia processual e nos critérios da coisa julgada secundum eventum litis, bem como na ampliação ope legis do objeto do processo, expressamente autoriza o transporte, in utilibus, da coisa julgada resultante de sentença proferida na ação civil pública para as ações individuais de indenização por danos pessoalmente sofridos".
} 
Afivele-se que o STJ ${ }^{41}$, ampliando a interpretação sobre o dispositivo legal invocado, tem permitido, em caso de ajuizamento de ação individual pelo consumidor, em concomitância com Ação Civil Pública, que, em havendo condenação nesta, a demanda do primeiro se converta diretamente em processo de liquidação, em nome da economia e celeridade processual.

Em se cuidando de execução individual, relativa a direitos individuais homogêneos, a questão é inteiramente disciplinada no $C D C$, iniciando-se, a legitimidade ordinária, naturalmente pela vítima ou seus sucessores, a partir do art. $97^{42}$.

Admite, entretanto, a parte final do artigo mencionado, que a execução individual se promova pelos legitimados de que trata o art. 82 do CDC. O rol este que se assemelha a regra prevista no art. $5^{-}$da LACP.

Em tais casos não há que se falar em substitutos processuais. Os legitimados, a exemplo de uma associação ou sindicato, agem em nome e na defesa dos interesses dos representados, como se a própria vítima demandasse em juízo. Não obstante a existência de certa discussão doutrinária sobre a natureza jurídica do instituto, alguns entendendo que se trata de um caso de legitimidade autônoma, o entendimento dominante, todavia, é que a situação retrata uma hipótese de representação processual.

Com efeito, o STJ, em oposição à esta concepção, tem pronunciado que o caso radiografa um caso de substituição processual ${ }^{43}$, pelo que, em termos práticos, não se exige a prévia concordância do representado/vítima para a assunção da execução pelo ente coletivo, facilitando, a tal ponto a defesa de tais direitos.

Seja como for, tecnicamente, não se estará diante de uma execução coletiva ${ }^{44}$, uma vez que o dano é individual. Trata-se de uma execução "pseudocoletiva" formada por parcelas identificadas de direitos individuais, o que na situação concreta pode acarretar um grande tumulto processual se os danos sofridos não forem uniformes (TARTUCE; NEVES, 2015, p. 743).

Discute-se, outrossim, se o Ministério Público, que possui legitimidade para o ajuizamento de Ações Civis Públicas, na forma do art. 82, I do CDC, poderia, igualmente, promover a execução coletiva em favor das vítimas.

A doutrina de uma maneira geral rejeita tal possibilidade. Sustenta-se que a legitimidade do Parquet estaria restrita à fase de conhecimento, uma vez que ainda estaria mantida a homogeneidade do direito com uma indeterminação dos lesados. A partir, contudo, do trânsito em julgado, havendo vítimas identificáveis, faleceria a este órgão atribuição constitucional para tanto, desviando-se de seu perfil institucional, na diç̧ão do art. 127, c/c o art. 129, III da $\mathrm{CR} / 88$, que somente faz menção a interesses difusos e coletivos (mas não a individuais

41STJ - Agravo regimental no agravo em recurso especial. Ação coletiva. Execução individual. Liquidação prévia. Necessidade. Divergência jurisprudência. Ausência de similitude. SÚMULAS № 7/STJ E 284/STF. 1. É necessária a liquidação sentença coletiva proferida em ação civil pública pelo particular que pretende executá-la, oportunidade em que se provará tanto a sua qualidade de credor quanto o valor do seu crédito.2. Os julgados trazidos como paradigmas solucionaram questão relacionada à possibilidade de conversão de ação individual em liquidação de sentença, quando julgada ação coletiva com o mesmo objeto, o que não se assemelha à pretensão recorrente, para que se converta execução individual de sentença coletiva em liquidação. Incidência das Súmulas no $7 / \mathrm{ST}$ ) e 284/STF. 3. Agravo regimental não provido. (AgRg no AREsp 370.244/SP, Rel. Ministro Ricardo Villas Bôas Cueva, terceira turma, julgado em 15/10/2015, DJe 23/10/2015).

42 Art. 97. "A liquidação e a execução de sentença poderão ser promovidas pela vítima e seus sucessores, assim como pelos legitimados de que trata o art. 82".

43 STJ - Administrativo. Servidor público. Agravo interno em recurso especial. Ação coletiva. Sindicato. Substituição processual. Execução individual. Servidor não filiado. Legitimidade. Agravo interno desprovido. 1. Este Superior Tribunal consagrou orientação segundo a qual, consoante disposição da Súmula 629/STF, o sindicato, na qualidade de substituto processual, atua na esfera judicial na defesa dos interesses coletivos de toda a categoria que representa, sendo dispensável a relação nominal dos filiados e suas respectivas autorizações. 2. Assim, o servidor público integrante da categoria beneficiada, desde que comprove essa condição, tem legitimidade para propor execução individual, ainda que não ostente a condição de filiado ou associado da entidade autora da ação de conhecimento. 3. Agravo interno não provido. (AgInt no REsp 1689334/RJ, Rel. Ministro Mauro Campbell Marques, segunda turma, julgado em 15/03/2018, DJe 20/03/2018).

44 Art. 98. "A execução poderá ser coletiva, sendo promovida pelos legitimados de que trata o art. 82, abrangendo as vítimas cujas indenizações já tiveram sido fixadas em sentença de liquidação, sem prejuízo do ajuizamento de outras execuções”. 
homogêneos), remanescendo a questão somente em termos patrimoniais. O STJ ${ }^{45}$ segue esta linha de raciocínio.

Permite ainda, residualmente, o art. 100 do $\mathrm{CDC}^{46}$ que em caso de inércia das vítimas ou em havendo habilitação em número incompatível com a extensão do dano, os legitimados do art. 82 possam promover a liquidação, caso em que a indenização será revertida para o fundo.

Cuida-se de uma curiosa espécie de "repristinação" de legitimidade extraordinária subsidiária. Nesse ponto, inexiste impedimento ideológico para a atuação do Ministério Público, vez que a indenização não será destinada à nenhuma vítima, mas sim a um fundo.

A regra legal tem vasta aplicação nos casos em que ocorre uma diminuta lesão aos consumidores, mas ampla projeção econômica para os produtores. É a chamada "grande dispersão de pequenas quantidades". Imagine-se, como exemplo, que um fabricante de papel higiênico reduza o tamanho do rolo em apenas $5 \mathrm{~cm}$, ou o produtor de iogurtes que diminua a quantidade do laticínio no pote ou industrial de sardinhas coloque mais óleo do que peixe dentro da lata ${ }^{47}$.

Em todos esses casos dificilmente o consumidor lesado perderá o seu precioso tempo buscando a tutela jurisdicional, dado o diminuto dano em sua feição individual. Entretanto, para o fabricante, tais reduções ensejam um aumento exponencial dos lucros, em prejuízo de todos, em franca ilicitude, autorizando-se o uso da medida de reparação legal.

Apesar de ser um grande instrumento a favor da tutela processual dos interesses dos consumidores, a disposição normativa não é clara em alguns pontos, o que faz render divergências doutrinárias. A primeira delas, diz respeito ao termo inicial da contagem do prazo dos 100 dias ${ }^{48}$ para o start dessa legitimidade residual.

45 STJ - Processo Civil. Direito do Consumidor. Recurso Especial. Ação de liquidação de sentença prolatada em Ação Civil Pública. Direitos individuais homogêneos. Precedência da legitimidade das vítimas ou sucessores. Subsidiariedade da legitimidade dos entes indicados no art. 82 do CDC. 1. A legitimidade para intentar ação coletiva versando a defesa de direitos individuais homogêneos é concorrente e disjuntiva, podendo os legitimados indicados no art. 82 do CDC agir em Juízo independentemente uns dos outros, sem prevalência alguma entre si, haja vista que o objeto da tutela se refereà coletividade, ou seja, os direitos são tratados de forma indivisível. 2. Todavia, para o cumprimento de sentença, o escopo é o ressarcimento do dano individualmente experimentado, de modo que a indivisibilidade do objeto cede lugar à sua individualização. 3. Não obstante ser ampla a legitimação para impulsionar a liquidação e a execução da sentença coletiva, admitindo-se que a promovam o próprio titular do direito material, seus sucessores, ou um dos legitimados do art. 82 do CDC, o art. 97 impõe uma gradação de preferência que permite a legitimidade coletiva subsidiariamente, uma vez que, nessa fase, o ponto central é o dano pessoal sofrido por cada uma das vítimas. 4. Assim, no ressarcimento individual (arts. 97 e 98 do CDC), a liquidação e a execução serão obrigatoriamente personalizadas e divisíveis, devendo prioritariamente ser promovidas pelas vítimas ou seus sucessores de forma singular, uma vez que o próprio lesado tem melhores condições de demonstrar a existência do seu dano pessoal, o nexo etiológico com o dano globalmente reconhecido, bem como o montante equivalente à sua parcela. 5. O art. 98 do CDC preconiza que a execução "coletiva” terá lugar quando já houver sido fixado o valor da indenização devida em sentença de liquidação, a qual deve ser - em sede de direitos individuais homogêneos - promovida pelos próprios titulares ou sucessores. 6. A legitimidade do Ministério Público para instaurar a execução exsurgirá - se for o caso - após o escoamento do prazo de um ano do trânsito em julgado se não houver a habilitação de interessados em número compatível com a gravidade do dano, nos termos do art. 100 do CDC. É que a hipótese versada nesse dispositivo encerra situação em que, por alguma razão, os consumidores lesados desinteressam-se quanto ao cumprimento individual da sentença, retornando a legitimação dos entes públicos indicados no art. 82 do CDC para requerer ao Juízo a apuração dos danos globalmente causados e a reversão dos valores apurados para o Fundo de Defesa dos Direitos Difusos (art. 13 da LACP), com vistas a que a sentença não se torne inócua, liberando o fornecedor que atuou ilicitamente de arcar com a reparação dos danos causados. 7. (...) 8. No momento em que se encontra o feito, o Ministério Público, a exemplo dos demais entes públicos indicados no art. 82 do CDC, carece de legitimidade para a liquidação da sentença genérica, haja vista a própria conformação constitucional desse órgão e o escopo precípuo dessa forma de execução, qual seja, a satisfação de interesses individuais personalizados que, apesar de se encontrarem circunstancialmente agrupados, não perdem sua natureza disponível. 9. Recurso especial provido. (REsp 869.583/DF, Rel. Ministro Luis Felipe Salomão, quarta turma, julgado em 05/o6/2012, DJe 05/09/2012).

46 Art. 10o. "Decorrido o prazo de um ano sem habilitação de interessados em número compatível com a gravidade do dano, poderão os legitimados do art. 82 promover a liquidação e execução da indenização devida”.

47 Para uma análise mais destacada da jurisprudência vide o REsp 1586515/RS, Rel. Ministra Nancy Andrighi, terceira turma, julgado em 22/05/2018, DJe 29/05/2018, em que são tecidas considerações a respeito dos direitos individuais homogêneos, legitimidade do Ministério Público e dano moral coletivo em situações de grande dispersão de pequenas quantidades ("sardinha em conserva"). 48 Chamo a atenção para informar que, no caso de proteção dos investidores do mercado de valores mobiliários, o prazo será de o2 anos, na forma do art. 2º, §2º da lei 7.913/89. 
Assim, sem embargo de outras posições doutrinárias ${ }^{49}$, a postura mais adequada, dentro de um ideal de segurança jurídica, é aquela que preconiza que o prazo do art. 100 do CDC tem início com o trânsito em julgado da sentença condenatória, à luz da regra prevista no art. 16 da $\mathrm{LACP}^{50}$, em virtude de uma interpretação circular dentro da esfera do microssistema da tutela coletiva. O ST ${ }^{51}$ também abraça essa orientação.

À toda evidência, tal prazo não possui natureza decadencial ou prescricional. Isto é, ultrapassado o marco temporal, ainda assim as vítimas lesadas poderão se valer do Judiciário, a fim de buscar a recomposição de seu patrimônio. Haverá, pois, uma concorrência de execuções entre os legitimados do art. 82 do CDC - em legitimidade extraordinária residual - visando o incremento econômico uma reparação fluida para o fundo; e das vítimas - em legitimidade ordinária, inaugurando-se um concurso de crédito $^{52}$, nos termos do art. 99 do CDC, com preferência de recebimento para estas.

A lei também não descreve o que seria a inexistência de habilitação de interessados em número compatível com a gravidade do dano. Cuida-se de conceito jurídico indeterminado. Nesse ponto a doutrina tem preconizado a adoção de um critério econômico apontando como razoável o ilegal lucro obtido pelo responsável do ato ilícito (GOMES JÚNIOR, 2008, p. 363).

\section{COMPETÊNCIA}

Outra questão digna de nota se refere ao juízo competente para o cumprimento da sentença. É intuitivo, nos termos do art. 516, II do CPC/15, que o juízo que decidiu a causa no primeiro grau de jurisdição seja o competente para a execução do título judicial. O raciocínio nada mais é do que a adoção do critério legal de competência funcional.

É nestes termos que foi cunhado o art. 98, §2º, I e II do CDC53. A regra, então, está em consonância os ditames do Código de Processo Civil. Executa-se a decisão no juízo que a proferiu.

49 Para Luiz Manoel Gomes Junior (2008, p. 362), o prazo deveria se iniciar com a publicação da decisão em primeira instância, ou seja, em período anterior à formação da coisa julgada, uma vez que inexiste regra expressa e eventual recurso é despido de efeito suspensivo. Para Ada Pellegrini Grinover et al (1999, p. 785), o prazo deveria ser contado da publicação de um edital após a sentença, com ampla informação aos consumidores, a respeito da condenação, em analogia ao art. 94 do CDC, sob pena de a condenação tornar-se inócua.

50 Art. 15. "Decorridos sessenta dias do trânsito em julgado da sentença condenatória, sem que a associação autora lhe promova a execução, deverá fazê-lo o Ministério Público, facultada igual iniciativa aos demais legitimados”.

${ }^{1}$ STJ - Recurso Especial - Direito do Consumidor - Agravo de Instrumento - Ação Coletiva - interesses individuais homogêneos sentença de procedência - liquidação e execução da sentença genérica requerida pelo ministério público, com fundamento no art. 100 do CDC (fluid recovery) - pedido indeferido pelas instâncias ordinárias, sob o argumento de que o transcurso do prazo de um ano deve ter como termo inicial a publicação de editais em jornais de ampla circulação, obrigação a que foram condenados os réus - impossibilidade de se condicionar o início do referido prazo ao cumprimento da citada obrigação de fazer. Insurgência recursal do ministério público estadual. (...) 1. (...) 2. Nos termos do artigo 100, caput, do Código de Defesa do Consumidor, "decorrido o prazo de um ano sem habilitação de interessados em número compatível com a gravidade do dano, poderão os legitimados do art. 82 promover a liquidação e execução da indenização devida", hipótese denominada reparação fluida - fluid recovery, inspirada no modelo norte-americano da class action. 2.1. Referido instituto, caracterizado pela subsidiariedade, aplica-se apenas em situação na qual os consumidores lesados desinteressam-se quanto ao cumprimento individual da sentença coletiva, transferindo à coletividade o produto da reparação civil individual não reclamada, de modo a preservar a vontade da Lei, qual seja a de impedir o enriquecimento sem causa do fornecedor que atentou contra as normas jurídicas de caráter público, lesando os consumidores. 2.2. Assim, se após o escoamento do prazo de um ano do trânsito em julgado, não houve habilitação de interessados em número compatível com a extensão do dano, exsurge a legitimidade do Ministério Público para instaurar a execução, nos termos do mencionado artigo 100 do Código de Defesa do Consumidor; nesse contexto, conquanto a sentença tenha determinado que os réus publicassem a parte dispositiva em dois jornais de ampla circulação local, esta obrigação, frise-se, destinada aos réus, não pode condicionar a possibilidade de reparação fluida, ante a ausência de disposição legal para tanto e, ainda, a sua eventual prejudicialidade à efetividade da ação coletiva, tendo em vista as dificuldades práticas para compelir os réus ao cumprimento. 2.3. (...) (REsp 1156o21/RS, Rel. Ministro MARCO BUZZI, QUARTA TURMA, julgado em 06/02/2014, DJe 05/05/2014).

52 Art. 99. "Em caso de concurso de créditos decorrentes de condenação prevista na Lei $n^{\circ} 7 \cdot 347$, de 24 de julho de 1985 e de indenizações pelos prejuízos individuais resultantes do mesmo evento danoso, estas terão preferência no pagamento".

53 Art. 98 (...) § $2^{\circ}$ "É competente para a execução o juízo: I - da liquidação da sentença ou da ação condenatória, no caso de execução individual; II - da ação condenatória, quando coletiva a execução". 
Em termos de execução coletiva propriamente dita, a disposição legal não cria embaraços ou empecilhos, continuando o juízo de origem competente para o cumprimento da sentença. De outro lado, quando se tratar de execuções individuais, em que seja indispensável a prévia "liquidação de sentença", é que se questiona a possibilidade de ajuizamento no foro de domicílio do consumidor.

A lei 8.078/9o, no parágrafo único, do art. 97, continha tal previsão. Em outras palavras, admitia-se o foro de domicílio do liquidante. Ocorre que o dispositivo foi vetado ${ }^{54}$, erroneamente, sob a premissa de dissociação do sistema conhecimento-execução, o que violaria a ampla defesa.

Não faz sentido, contudo, que proferida uma sentença condenatória em uma determinada comarca, todos os lesados de um mesmo Estado - consoante o âmbito de abrangência da coisa julgada (art. 16 da LACP) - estejam sujeitos ao mesmo juízo. Tal situação gera um contrassenso, uma inversão axiológica de tutela consumerista.

Basta ver que tal postura afronta o Acesso à Justiça daqueles que residem em Regiões afastadas do juízo de origem, o que contribui para o descrédito das ações coletivas, bem como atenta contra a Administração da Justiça, uma vez que concentrar todas as execuções em um único juízo, significa emperrar toda a máquina judicial acabando com o ideal de pronta e célere prestação jurisdicional.

Ademais, oart.101, IdoCDCadmiteque o consumidor possa ajuizar demandas individuais no local de seu domicílio. Ora, em havendo possibilidade de demandar originariamente neste local a regra deve ser interpretada extensivamente para os casos de liquidação e execuções individuais decorrentes de condenações coletivas, podendo, inclusive, haver preleção pelo foro do executado ou mesmo no local em que se encontre os bens do devedor, por aplicação subsidiária do CPC. É o que apregoa a doutrina sobre o problema (CERDEIRA, 2008, o6).

Felizmente, o ST) 55 , em sede de recurso repetitivo, já resolveu a questão.

\section{MEIOS EXECUTIVOS}

Os meios executivos constituem a técnica processual empregada para a entrega do bem da vida assegurada no título executivo. É, portanto, uma relação de meio e fim, de tutela e de ato. Os meios correspondem, pois, aos atos processuais de natureza sub-rogatória (meios diretos) ou coercitiva (meios indiretos).

É justamente através dos meios executivos que se concentra e se realiza a função executiva. E a execução depende, pois, de um arcabouço instrumental apto à realização do

\footnotetext{
54 "Art. 97 - Parágrafo único - "A liquidação de sentença, que será por artigos, poderá ser promovida no foro do domicílio do liquidante, cabendo-lhe provar, tão-só, o nexo de causalidade, o dano e seu montante”.

Razões do Veto: Esse dispositivo dissocia, de forma arbitrária, o foro dos processos de conhecimento e de execução, rompendo o princípio da vinculação quanto à competência entre esses processos, adotado pelo Código de Processo Civil (Art. 575) e defendido pela melhor doutrina. Ao despojar uma das partes da certeza quanto ao foro de execução, tal preceito lesa o princípio de ampla defesa assegurado pela Constituição (Art. 5ํㅡ. LV).

55 STJ - Processual Civil. Ação Coletiva. Execução coletiva ajuizada. Prevenção do juízo para fins de promoção da execução individual. Não ocorrência. Arts. 98, caput, § 2º, i, e 101, i, do CDC. Avocação pelo juízo da ação coletiva. Não constatação. 1. A Corte Especial do STJ fixou, sob o rito do art. 543-C do CPC e da Resolução STJ 8/20o8, que "a liquidação e a execução individual de sentença genérica proferida em ação civil coletiva pode ser ajuizada no foro do domicílio do beneficiário” (REsp 1.243.887/PR, Rel. Ministro Luis Felipe Salomão, Corte Especial, DJe 12.12.2011). 2. (...) 3. Obrigar os beneficiados pela sentença coletiva a liquidá-la e a executá-la no foro em que a ação coletiva foi julgada implica inviabilização da tutela dos direitos individuais. 4. A interpretação conjunta dos arts. 98, caput, § 2º, I, e 101, I, do CDC leva à conclusão de que o ajuizamento da execução coletiva não torna prevento o respectivo juízo para fins de execução individual, sob pena de tornar letra morta a garantia, referida no acórdão embargado, à efetivação da tutela dos interesses individuais albergados pela ação coletiva, consubstanciada na possibilidade de ajuizamento da demanda executória individual no foro de domicílio do credor. 5. É irrelevante o fato de a execução ter se iniciado nos autos da ação coletiva e continuar na ação de execução individual, em face do caráter disjuntivo de atuação dos legitimados e da expressa previsão da possibilidade do concurso de créditos (art. 99 do CDC). 6. (...) 7. Agravo Regimental não provido. (AgRg no REsp 1432236/SC, Rel. Ministro Herman Benjamin, segunda turma, julgado em 13/05/2014, DJe 23/05/2014).
} 
direito material, sob pena de virar um mero discurso acadêmico, a fim de que a obrigação contida no título salte do papel, a fim de que a Justiça não seja uma mera ilusão ${ }^{56}$.

Pois bem, na chamada execução direta ou por sub-rogação, o Estado substituindo a vontade do devedor, realiza, sobre o patrimônio deste, o direito do credor. É o caso típico de expropriação.

Já na execução indireta ou por coerção, o Estado não substitui o devedor. Ao revés, se vale de medidas que constrangem a sua vontade. Não há aqui sub-rogação. O resultado é alcançado com o concurso da ação do devedor, pressionado em seu comportamento ao atendimento da obrigação.

Aqui reside o maior alcance da tutela coletiva e dele depende a sua credibilidade. $\mathrm{O}$ seu núcleo de atuação e a sua feição completamente inovadora, do ponto de vista normativo, reside na previsão contida no art. 11 da LACP, ao admitir, pela primeira vez, uma tutela específica de tal magnitude, com a adoção de uma atipicidade de meios de obtenção do resultado prático equivalente ao adimplemento, em clara oposição à sistemática geral prevista no CPC de então.

A distinção é digna de nota. Enquanto o $\mathrm{CPC} / 73$, em sua redação originária, mantinha o dogma da intangibilidade da vontade em seu art. 63857, determinando que, em caso de descumprimento a obrigação, a mesma seria convertida em perdas e danos, dando azo a uma tutela ressarcitória, a LACP, já 1985, trilhou um caminho oposto para buscar a tutela específica da obrigação, em detrimento da realização pecuniária do direito.

A questão não é difícil de entender. É que certos direitos difusos, como a água, o ar, o meio ambiente, a fauna e a flora, embora sejam bens jurídicos, não possuem valor econômico intrínseco. Logo a condenação pecuniária pelo dano provocado a tais bens produz muito pouco ou nenhum benefício, no que toca à recomposição ou prevenção de novas condutas lesivas ${ }^{5}$.

Em sentido diametralmente oposto, o art. 11 da LACP admite, desde aquele tempo, que nas obrigações de fazer e não fazer o juiz determinasse o cumprimento da obrigação, sob pena de execução específica, podendo, inclusive, modificar as medidas independentemente de requerimento do autor. Excepcionava-se a um só tempo, o princípio da tipicidade de meios previsto no $\mathrm{CPC} / 73$, bem assim o princípio da inércia.

Esse dispositivo legal, é bom ressaltar, inspirou diversas legislações. É o caso do art. 84 do CDC; art. 213 do ECA; art. 83 do Estatuto do Idoso; art. 95 da Lei de defesa da Concorrência e o antigo art. 461e art. 461-A do CPC/73, além de outras. Atualmente se encontra encartado no art. $536^{59}$ no $\mathrm{CPC} / 2015$, sendo uma típica situação de influência do especial no geral.

Isto é, o que hoje é facilmente encontrado nas legislações atuais e soa natural no ordenamento jurídico, na época foi um verdadeiro alarde, um rompimento com os entraves e

56 É pertinente a crítica de Araken de Assis (1996, p. 02) quando informa que: “Compreendem-se, nesta contingência, as causas da grave crise contemporânea da função executiva, que reformas da verba legislativa em nada mitigam. Em geral, se desconhecem os procedimentos executivos. A estrutura legislativa se mostra deficiente. Os estudiosos ignoram esta rica e inexplorada província do processo civil. E as medidas executivas, que representam o núcleo das formas de atuação coativa de direitos, beiram à obsolescência. Tudo isto não desmerece a singular relevância do processo executivo. Ele se destina à realização dos direitos, e, neste sentido, constitui a forma mais expressiva, na perspectiva do jurisdicionado, de tutela jurisdicional".

57Art. 638. "Nas obrigações de fazer, quando for convencionado que o devedor a faça pessoalmente, o credor poderá requerer ao juiz que Ihe assine prazo para cumpri-la. Parágrafo único. Havendo recusa ou mora do devedor, a obrigação pessoal do devedor converter-se-á em perdas e danos, aplicando-se outrossim o disposto no art. 633”.

58 Ensinava Barbosa Moreira que: "em grande número de hipóteses é irreparável a lesão consumada ao interesse coletivo: nada seria capaz de reconstituir a obra de arte destruída, nem de restaurar a rocha que aformoseava a paisagem; inexiste, ademais, prestação pecuniária que logre compensar adequadamente o dano, insuscetível de medida por padrões econômicos. Em poucas matérias se revela de modo tão eloquente como nesta a insuficiência da tutela repressiva, exercitada mediante a imposição de sanções e quando necessário, pela execução forçada da condenação. O que mais importa é evitar a ocorrência da lesão; daí o caráter preventivo que deve assumir, de preferência, a tutela jurisdicional”. Moreira, José Carlos. A proteção jurisdicional dos interesses coletivos ou difusos. In a tutela dos interesses difusos. Coordenadora Ada Pellegrini Grinover. $1^{\underline{a}}$ ed. São Paulo. Max Limond. 1984. p. 102.

59 Art. 536. No cumprimento de sentença que reconheça a exigibilidade de obrigação de fazer ou de não fazer, o juiz poderá, de ofício ou a requerimento, para a efetivação da tutela específica ou a obtenção de tutela pelo resultado prático equivalente, determinar as medidas necessárias à satisfação do exequente. 
limitações típicas das lides individuais, o que de certa maneira, aos olhos mais desconfiados, fragilizava a segurança jurídica ao conceder, supostamente, mais faculdades ao julgador.

O tempo passou e as desconfianças cessaram. Tanto assim, que o novo Código de Processo Civil outorgou ao magistrado, no art. 139, IV ${ }^{60}$, um poder geral executivo, por meio de uma cláusula geral que se aplica a todo o ordenamento.

Evidentemente, a par dos diversos meios executivos, sem dúvida, a multa processual é a estrela de primeira grandeza. Conhecida como astreintes, por influência francesa, a multa, como meio coercitivo assumiu um papel de destaque, não podendo haver desprezo quanto as demais modalidades, a exemplo da busca e apreensão, remoção, desfazimento, protesto, interdição de atividade/estabelecimento entre outras.

Não obstante, é a multa a protagonista dos meios coercitivos no cenário processual, a par do art. 11 da LACP.

Entrementes, com a entrada em vigor do novo Código de Processo Civil, dado o princípio de subsidiariedade (art. 19 LACP), alguns novos desafios foram lançados com repercussão na tutela coletiva.

O primeiro deles é referente à possibilidade de redução da multa vencida, forte na regra do art. 536, §1을 do $\mathrm{CPC} / 2015^{6}$. A questão não é meramente teórica e assume contornos de alta relevância prática.

É sabido que a multa ostenta natureza processual não se submetendo aos efeitos de imutabilidade da coisa julgada, tampouco à preclusão judicial ${ }^{62}$. Com efeito, a novel disposição promove uma verdadeira amarra judicial permitindo, em sua literalidade, a modificação com caráter ex nunc, ou seja, com efeito prospectivo, mas sem possibilidade de mudança em seu aspecto retroativo. A doutrina ${ }^{63}$ é vacilante sobre o tema e a jurisprudência ${ }^{64} /{ }^{65}$ ainda não

6oArt. $139 \mathrm{IV}$ - determinar todas as medidas indutivas, coercitivas, mandamentais ou sub-rogatórias necessárias para assegurar o cumprimento de ordem judicial, inclusive nas ações que tenham por objeto prestação pecuniária.

61 Art. 537. "A multa independe de requerimento da parte e poderá ser aplicada na fase de conhecimento, em tutela provisória ou na sentença, ou na fase de execução, desde que seja suficiente e compatível com a obrigação e que se determine prazo razoável para cumprimento do preceito. $\S 1^{\circ} \mathrm{O}$ juiz poderá, de ofício ou a requerimento, modificar o valor ou a periodicidade da multa vincenda ou excluí-la, caso verifique que: I - se tornou insuficiente ou excessiva; II - o obrigado demonstrou cumprimento parcial superveniente da obrigação ou justa causa para o descumprimento".

62 STJ - Recurso especial representativo da controvérsia. Processual civil. Expurgos inflacionários. Caderneta de poupança. Cumprimento de sentença. Exibição de extratos bancários. Astreintes. Descabimento. Coisa julgada. Inocorrência. 1. Para fins do art. 543-C do CPC: 1.1. "Descabimento de multa cominatória na exibição, incidental ou autônoma, de documento relativo a direito disponível." 1.2. "A decisão que comina astreintes não preclui, não fazendo tampouco coisa julgada." 2. Caso concreto: Exclusão das astreintes. 3 . Recurso especial provido. (REsp 1333988/SP, Rel. Ministro Paulo de Tarso Sanseverino, segunda seção, julgado em og/o4/2014, DJe 11/04/2014)

63 Preciosas são as lições de Daniel Amorim Assumpção Neves sobre o tema: "Pode o juiz reduzir o valor que será executado pela parte? Seria possível aplicar o art. 537, § 1o, do Novo CPC a essa situação, ou o dispositivo legal limita-se a tutelar as situações em que a multa ainda está sendo aplicada? Há defensores da impossibilidade de o juiz diminuir o valor final gerado pela frustração da multa. Alguns doutrinadores simplesmente afirmam que não há base legal para o juiz retroativamente eximir parcial ou totalmente o devedor, enquanto outros defendem a impossibilidade de o juiz fazer tal revisão com fundamento no direito adquirido da parte beneficiada com o direito de crédito advindo da frustração da multa. O entendimento é interessante, mas não deve ser admitido, ao menos não em sua integralidade. Em meu entendimento, enquanto a multa mostrou concreta utilidade em pressionar o devedor, o valor obtido é realmente um direito adquirido da parte, não podendo o juiz reduzi-lo, ainda que instado a tanto pela parte contrária. Mas isso não significa que o valor calculado durante todo o tempo de vigência da multa seja efetivamente devido, porque a partir do momento em que a multa teve o seu objetivo frustrado, perdendo a sua função, a sua manutenção passaria a ter caráter puramente sancionatório, com nítido desvirtuamento de sua natureza. O mais adequado é o juiz determinar, com eficácia ex tunc, a partir de quando a multa já não tinha mais utilidade, revogando-a a partir desse momento e calculando o valor somente relativamente ao período de tempo em que a multa se mostrou útil. Reconheço que a determinação exata do momento a partir de quando a multa passou a ser inútil pode ser extremamente difícil, mas caberá ao juiz determiná-lo valendo do princípio da razoabilidade”. (Manual de Processo Civil. Volume único. 8a ed. Jus Podivum. p. 2011/2012).

64 Contra a redução: TJSP - Agravo de instrumento - Ação civil pública - Cumprimento de sentença - Multa por descumprimento de obrigação de fazer - Alegação de desproporcionalidade e excesso - Inocorrência - Aplicabilidade da multa já decidida em outra decisão, confirmada em sede recursal - Preclusão - Redução - Impossibilidade - Multa que é vencida, não vincenda - Art. 537, §1º, do CPC - Recurso improvido (TJSP; Agravo de Instrumento 2223994-49.2017.8.26.oooo; Relator (a): Miguel Petroni Neto; Órgão Julgador: 2 ${ }^{\text {a }}$ Câmara Reservada ao Meio Ambiente; Foro de Tanabi - 2 $\mathbf{a}$ Vara; Data do Julgamento: 17/o5/2018; Data de Registro: 24/o5/2018). 65 A favor da redução: TJSP - AGRAVO DE INSTRUMENTO - AÇÃO DE OBRIGAÇÃO DE FAZER - EXECUÇÃO DE MULTA DIÁRIA - insurgência em face da decisão pela qual foi parcialmente acolhida a impugnação ofertada pelo agravado para o fim de redução do valor total da multa cominatória, de $\mathrm{R} \$ 85.600$,oo para $\mathrm{R} \$ 10.400,00$ - descumprimento pelo banco agravado da ordem judicial de apresentação de informações acerca de financiamentos contratados pela agravante - valor total atingido pela multa que realmente 
sedimentou o assunto. No âmbito do TJRJ, o Centro de Estudos e Debates - CEDES - editou por meio do Aviso conjunto TJ/CEDES 22/2015, o Enunciado 80 ${ }^{66}$, nos seguintes termos: "Pode o juiz reduzir o valor ou modificar a periodicidade da multa cominatória vencida, se não houver decisão anterior preclusa que a consolide".

Outro aspecto que chama a atenção repousa da dicção do $\$ 3^{\circ}$ do art. $537^{67}$ do CPC/2015 ao admitir a execução provisória da multa estando em rota de colisão com o art. 12, $\$ 2^{\mathbf{o}^{68}}$ da LACP que somente admite a sua exigibilidade após o trânsito em julgado.

Com esse espectro, a disciplina prevista no novo CPC se mostra muito mais favorável do que na tutela coletiva. Faculta-se, ainda que de modo não definitivo, a exigibilidade da multa, constrangendo de tal monta o devedor ao cumprimento da obrigação. Do contrário, aguardar o trânsito em julgado para, e somente após, decorrido um longo tempo de batalha judicial, é atentar para os ditames da efetividade processual.

Com esse panorama é que se defende uma interpretação evolutiva para se admitir também, na execução coletiva, a possibilidade de execução provisória da pena de multa como fator condicionante de uma tutela efetiva e adequada. Esse também é o entendimento formulado no Fórum Permanentes de Processualistas (FPP) ${ }^{69}$.

\section{CONSIDERAÇÕES FINAIS}

Decorrido mais de 30 anos da Lei da Ação Civil Pública, a tutela coletiva ainda se mantém uma solene desconhecida para grande parcela do mundo jurídico. Muitos, em uma visão míope e distorcida, ainda a enxergam com os olhos voltados para os institutos de índole particular.

Urge mudar essa cultura, descortinar esse novo horizonte, a fim de transmutar o perfil das demandas com o objetivo de enxugar o demandismo individual que somente serve ao abarrotamento da Justiça.

Novos instrumentos foram outorgados ao Judiciário com o escopo de cumprir a sua missão constitucional. Novas questões surgiram, mas velhos problemas ainda não foram resolvidos.

É preciso avançar em termos legislativos sobre a tutela coletiva, caso contrário permaneceremos nesse terreno pantanoso de baixa efetividade e pouca credibilidade, a

se mostrou exagerado e desproporcional ao conteúdo econômico da demanda, implicando enriquecimento sem causa da agravante - possibilidade de redução do valor da multa vencida, mesmo sob a vigência do CPC/2015 - interpretação histórica e sistemática do art. 537, § 1 o do referido diploma legal - vedação do enriquecimento sem causa - princípio geral do direito - decisão mantida - agravo desprovido. (TJSP; Agravo de Instrumento 2008394-35.2018.8.26.oooo; Relator (a): Castro Figliolia; Órgão Julgador: 12a Câmara de Direito Privado; Foro de Guará - 1a Vara; Data do Julgamento: 16/05/2018; Data de Registro: 16/05/2018)

66 Sob a seguinte justificativa: "A decisão que fixa a astreinte leva em consideração uma margem periódica de inadimplência estimada que, eventualmente, poderá ser suplantada pelo período de inadimplência efetivo. Esta distorção (que pode chegar ao infinito) representa fato novo, não abrangido pelos efeitos preclusivos da decisão que estipulou o valor ou periodicidade inicial da multa. Logo, a correta interpretação do art. 537, §1º do CPC não pode ser literal, no sentido da vedação da modificação de multas vencidas. Ressalva-se, contudo, situação em que decisão anterior já tenha consolidado a multa pretérita, visto que eventual distorção já teria sido objeto de cognição".

67 Art. 537. § 3ํㅜ "A decisão que fixa a multa é passível de cumprimento provisório, devendo ser depositada em juízo, permitido o levantamento do valor após o trânsito em julgado da sentença favorável à parte ou na pendência do agravo fundado nos incisos II ou III do art. 1.042".

68 Art. 12. $\S 2^{\mathbf{0}}$ "A multa cominada liminarmente só será exigível do réu após o trânsito em julgado da decisão favorável ao autor, mas será devida desde o dia em que se houver configurado o descumprimento".

69 Enunciado 627 do FPP (arts. 297, 537, §3º; art. 12, §º, Lei 7.347/1985). Em processo coletivo, a decisão que fixa multa coercitiva é passível de cumprimento provisório, permitido o levantamento do valor respectivo após o trânsito em julgado da decisão de mérito favorável. Contra: Daniel Amorim Assumpção Neves (2017, p. 730), para quem "As considerações e conclusões, entretanto, não são aplicáveis quando a multa for utilizada em um processo coletivo, já que, nesse caso, a exigibilidade está condicionada ao trânsito em julgado da decisão que a fixar. E por que esse tratamento distinto? Por opção do legislador. (...) Considero que até se pode criticar a opção legislativa, que de fato não parece ser acertada, mas não é possível simplesmente desprezar os dispositivos legais mencionados". 
despeito do contínuo esforço dos operadores do Direito, a fim de que a Execução, no auge de sua glória, não volte a ser a encarada como "gata borralheira" da ciência processual.

\section{REFERÊNCIAS}

ABELHA, Marcelo. Manual de execução civil. 5. ed. Rio de Janeiro: Forense. 2017.

ASSIS, Araken de. Execução na ação civil pública. Revista de Processo. São Paulo, vol. 82, p. 46-52, abr./jun. 1996.

Cumprimento de sentença. 2. ed. Rio de Janeiro: Forense. 2009.

ATAIIDEJUNIOR, Vicente de Paula. A execução individual da sentença coletiva após a lei 11.232/2005. In NERY JR, Nelson; WAMBIER, Luiz Rodrigues; WAMBIER, Teresa Arruda Alvim. Execução civil. Estudos em homenagem ao professor Humberto Theodoro Junior. São Paulo: RT. 2007.

BRASIL. Conselho Nacional de Justiça. Relatório Justiça em Números. 2017 (ano base 2016). Brasília, 2017. Disponível em: <http://www.cnj.jus.br/files/conteudo/arquivo/2017/12/ b6oa659e5d5cb79337945c1dd137496c.pdf>. Acesso em: 15 jul. 2018.

ENCONTRO NACIONAL DO PODER JUDICIÁRIO, 10. Metas Nacionais para 2017.

Brasília. Anais Eletrônicos... Brasília: CNJ. 2016. Disponível em: <http://www.cnj.jus.br/files/ conteudo/arquivo/2017/o2/a2f4fc314db2ec5f39bbo615aba58b6a.pdf>. Acesso em: 15 jul. 2018.

BRUSCATO, Wilges. Execução de tutela jurisdicional coletiva. São Paulo: Saraiva. 2009.

CAPPELLETTI, Mauro; GARTH, Bryan. Acesso à justiça. Tradução: Ellen Gracie Northfleet. Porto Alegre: Fabris, 1998.

CARVALHO NETO, Inácio de. Manual de Direito processual Coletivo. 4. ed. Curitiba: Juruá. 2016.

CERDEIRA, Eduardo de Oliveira. Execução/Cumprimento de sentença no processo Coletivo. Revista LTr. São Paulo. Legislação do Trabalho e Previdência Social, São Paulo, v. 72, n. 12, p. 1463-1476, dez. 2008.

CHIOVENDA, Giuseppe. Instituições de Direito Processual Civil, trad. Bras. De J. Guimarães Menegale, 3. ed. São Paulo: Saraiva. 1969.

DIDIER JR., Fredie; ZANETI JR., Hermes. Curso de Direito Processual Civil. v. 4 (Processo Coletivo). Bahia: Jus Podivum. 2009.

DINAMARCO, Candido Rangel. Instituições de Direito Processual Civil. v. 4, 3. ed. São Paulo: Malheiros. 2009.

DONIZETTI, Elpídio; CERQUEIRA, Marcelo Malheiros. Curso de processo coletivo. São Paulo: Atlas. 2010. 
GOMES JUNIOR, Luiz Manoel. Curso de Direito Processual Civil Coletivo. São Paulo: SRS Editora. 2008.

GRINOVER, Ada Pellgrini et al. Código de defesa do Consumidor comentado pelos autores do anteprojeto. 6. ed. São Paulo: Forense universitária. 1999.

LEONEL, Ricardo de Barros. Manual do Processo Coletivo. 3. ed. São Paulo: RT. 2013.

MARINONI, Luiz Guilherme; ARENHART, Sérgio Cruz; MITIDIERO, Daniel. Novo Curso de Processo Civil. v. 3, 3. ed. São Paulo: RT. 2017.

MAZZEI, Rodrigo; GONÇALVES, Tiago Figueiredo. Linhas Básicas Acerca da "Liquidação de Sentença” Coletiva. Revista Brasileira de Direito Processual - RBDPro, Belo Horizonte, ano 22, n. 87, p. 137-158, jul./set. 2014. Disponível em: <http://www.bidforum.com.br/PDIooo6. aspx?pdiCntd=181686>. Acesso em: 15 jul. 2018.

MOREIRA, José Carlos. A proteção jurisdicional dos interesses coletivos ou difusos. In GRINOVER, Ada Pellegrini (coord.). A tutela dos interesses difusos. 1. ed. São Paulo: Max Limond. 1984.

NEVES, Daniel Amorim Assunção. Manual de Processo Civil. 8. ed. Jus Podivum. 2017.

NUNES, Dierle. Curso de Direito Processual Civil. Fundamentos e Aplicação. 2. ed. Belo Horizonte: Fórum. 2013.

RESENDE JUNIOR, José Eduardo de. Juiz brasileiro opta pela replicação e automatização. Consultor Jurídico. 24 maio 2014. Disponível em: <https://www.conjur.com.br/2014-mai-24/ jose-chaves-jr-juiz-brasileiro-opta-replicacao-automatizacao>. Acesso em: 14 jul. 2018.

TARTUCE, Flávio; NEVES, Daniel Amorim Assumpção. Manual de Direito do Consumidor. 4. ed. São Paulo: Método. 2015.

WAMBIER, Luiz Rodrigues. Curso Avançado de processo Civil. v. 3, 16. ed. São Paulo: RT. 2018. 